\title{
MEASURING TEACHERS' PEDAGOGICAL CONTENT KNOWLEDGE USING MANY-FACET RASCH MODEL
}

\author{
Maryati $^{1 *}$, Zuhdan Kun Prasetyo ${ }^{2}$, Insih Wilujeng ${ }^{3}$, Bambang Sumintono ${ }^{4}$ \\ 1,2,3 Universitas Negeri Yogyakarta, Indonesia \\ ${ }^{4}$ Universiti Malaya, Malaysia \\ *e-mail: maryati@uny.ac.id
}

\begin{abstract}
In the context of teacher professional development and teacher certification, an objective measurement of teachers' Pedagogical Content Knowledge (PCK) is requried. This research is a case study to measure teachers' PCK within prospective middle school science teachers participating in an Indonesian teacher professional development program. The study used quantitative approach which involved multirater assessment analysed by Many-Facet Rasch Model (MFRM) to assess teachers' PCK in teaching a specific topic, i.e. "The Particulate Nature of Matter" (PNM). Researchers developed a rubric for items to measure teachers' enactment PCK for teaching that specific topic. The MFRM analysis of the data revealed item reliability, item validity, separation and unidimensionality fall within good category. The findings show prospective teachers need to improve their PCK specifically in terms of "knowledge of instructional strategies and representations for teaching science" dimension. However, for knowledge of science curriculum and knowledge of students' understanding in science dimension, the findings show that the participants were competent.
\end{abstract}

Keywords: pedagogical content knowledge, assessment, many-facet rasch model, teacher professional development

\section{MENGUKUR PEDAGOGICAL CONTENT KNOWLEDGE GURU DENGAN MANY-FACET RASCH MODEL}

\begin{abstract}
Abstrak: Dalam konteks pengembangan profesi guru dan sertifikasi guru, penilaian objektif terhadap Pedagogical Content Knowledge (PCK) guru diperlukan. Penelitian ini adalah studi kasus untuk mengukur performans PCK calon guru IPA SMP peserta program pengembangan profesi guru di Indonesia. Penelitian ini menggunakan pendekatan kuantitatif yang melibatkan penilai berganda yang dianalisis dengan Many-Facet Rasch Model (MFRM) untuk menilai PCK guru dalam mengajar topik spesifik, yaitu "sifat partikel materi". Peneliti mengembangkan item rubrik untuk mengukur hasil PCK calon guru dalam mengajar topik tersebut dan hasil analisis data dengan MFRM menunjukkan bahwa reliabilitas item, validitas item, separasi dan unidimensionalitasnya dalam kategori baik. Hasil analisis menemukan bahwa calon guru masih perlu meningkatkan kemampuan PCK mereka, khususnya dalam dimensi "pengetahuan tentang strategi dan penyajian pengajaran sains". Sementara itu, dalam dimensi "pengetahuan tentang kurikulum" dan "pengetahuan tentang pemahaman siswa terhadap sains, hasil analisis menunjukkan mereka sudah menguasai kompetensi.
\end{abstract}

Kata kunci: pedagogical content knowledge, penilaian, many-facet rasch model, pengembangan profesi guru

\section{INTRODUCTION}

Since Shulman introduced the notion of Pedagogical Content Knowledge (PCK) in 1987, studies on PCK have grown rapidly (Abell, 2008). It has become the focus of teacher professional development programs, it covers teachers' knowledge on students' success and failure in learning as well as specific teaching materials (Van Driel \& Berry, 2012). PCK is considered as an indicator of teachers and prospective teachers' competences in America and some other countries (AAAS, 1993; NRC, 1996; Shulman, 2015; NCATE, 2001; NSTA, 1995).

The concept of PCK becomes a guidance for teachers to transform contents through 
representation, examples, and experiences (Ball, Themes \& Phelps, 2008) and its not limited to teachers' knowledge of teaching certain topics, but it also refers to "what the teachers do in classrooms and their reasons" (Baxter \& Lederman, 1999, p.158). This gives an indication that PCK must be explored at two levels: the planned PCK and enacted PCK, which in turn will give a better and clearer understanding of how teachers design and implement PCK in their classrooms. The Planed PCK is an amalgam of teachers' content knowledge and pedagogical knowledge of learning strategies needed, so that certain science topics can be comprehensively understood by students. The enacted PCK, on the other hand, refers to the type of PCK that can be observed during learning processes. PCK is often tacit, measuring it could be difficult, complicated, and time consuming. Some researchers make it possible to investigate with more efficient (Rohaan, Taconis, \& Jochems, 2009), for instance the PCK rubric instrument for measuring purpose had been done by Park, Jang, Chen, \& Jung (2011).

The 2012 PCK Summit resulted in an agreement that the PCK model that can be tested as a teacher's professionalism is "a model of teacher professional knowledge and skill [TPK\&S] including PCK". This model introduces Pedagogical Content Knowledge (PCK) and skill, in which PCK is defined as both a knowledge base for planning and delivering a topic-specific instruction in a very specific classroom context and as a skill when engaged in the act of teaching. The TPK\&S is actually derived from the generic teacher professional knowledge bases (TPKB) referring to topicspecific professional knowledge (TSPK). The knowledge category of TSPK explicitly contributes that: (1) the teaching contents occur at the topic level and not at the disciplinary level; (2) this knowledge combines subject matter, pedagogy, and context; and (3) TSPK is recognized as knowledge possessed by the profession, allowing it to assume a normative role (Gess-Newsome, 2015). This concept has also been developed by Mavhunga \& Rollnick (2013) known as TSPCK (Topic-specific PCK).

Obviously teacher profesional preparation programs should emphasize more on "how to teach a specific topic" rather than "how to teach a subject". This means PCK in nature is dynamic, not static (Baxter \& Lederman, 1999) meaning that teachers' PCK can be developed all the time (Henze \& Van Driel, 2015). Therefore, novice teachers usually demonstrate low PCK (Pitjeng, 2014; Van Driel, De Jong, \& Verloop, 2002). Although PCK develops through teaching experiences, novice teachers' PCK can be developed through intensive training that collaborates with experts of content and pedagogy (Williams \& Lockley, 2012; Loughran, Mullhall, \& Berry, 2004; Loughran, Berry, \& Mulhall, 2006). This is a challenging task for pre-service teacher educators (Aydeniz \& Kirbulut, 2014).

Assessment of teacher's PCK is a prerequisite for any teacher professional development (Henze, Van Driel \& Verlop, 2008; Park \& Oliver, 2008; Nilsson, 2008). Much research has been carried out to capture and portray teacher's PCK (Loughran, et. al., 2006), yet little has been done to assess its quality, particularly in science education (Park \& Suh, 2015; Mavhunga \& Rollnick, 2011). This is due to the lack of clear operational definition (Smith \& Banilower, 2015). Some researchers such as Tamir (1988); and Magnusson, Krajcik, \& Borko (1999), have attempted to identify PCK components for assessing teacher's PCK. However, the PCK model that is widely applied in science education research is the one developed by Magnusson, et. al. (1999) which comprises five components such as Van Dijk \& Kattmann (2006); and Kind (2009) who applied this model to improve teacher quality.

Research on teacher professional development programs attract researchers from different parts of the world (Postholm, 2012; Widodo \& Riandi, 2013). Several studies suggest that the teacher professional development programs by Indonesian government apparently cannot effectively improve teachers' competencies (Rahman, Abdurahman, Kadariyanto, \& Rusminanto, 2015; Sumintono \& Subekti, 2015) and teachers who have received professional allowance sometimes are still considered incompetent (De Ree, Muralidharan, Pradhan, \& Rogers, 2018). This is seemingly due to teachers' lack of subject mastery or content knowledge (Al-Samarrai, Chang, Ragatz, Shaeffer, Stevenson, \& De Ree, 2013). Though content knowledge is prerequisite for developing TSPCK, the level of expertise of content 
knowledge is not always related to high TSPCK (Davidowitza \& Potgieterb, 2016). The failure of teacher training programs is apparently due to the absence of problem solving related to "what will be done in classrooms". Most teacher training programs focus more on how to help teachers to learn about broad theories of teaching, learning, or a subject matter as a discipline (Aydeniz \& Kirbulut, 2014). Meanwhile, Nealsen (2003) asserted that failure was caused by teacher training programs always involves a large number of participants and a wide range of curriculum content that leads to fewer opportunities for teachers to improve the material understanding and how to teach particular topics effectively.

Related to the teacher professional development program (Indonesian: Pendidikan Profesi Guru, $P P G$ ), it is necessary to measure teacher's PCK to evaluate the implementation of teacher training program. This study employed a quantitative analysis on middle school prospective science teachers' participating in that program. The researchers used a multi-rater assessment employing Many Facet Rasch model (MFRM) for quantitative data analysis. MFRM provides an accurate analysis result used to evaluate teachers' performances with a small number of subjects (Linacre, 2013). This quantitative study is an enacted PCK exploration focused on specific learning topics, that is "the particulate nature of matter" (PNM). The topic is the basis for understanding some chemical concepts and other scientific concepts (Snir, Smith, \& Raz, 2003; Tsai, 1999). The understanding of PNM can even improve learning achievement in chemistry (Gabel, 1991). Harrison \& Treagust (2002) recommend research on this topic to investigate both to science teachers and students. The aim of this study is to portray the PCK skill of middle school prospective science teacher and discuss their strengths and weaknesses by involved multirater assessment as a practice to achieve objective measurement.

\section{METHODS}

This is quantitative study on on teacher professional development in Indonesia which took place in a natural setting, where researchers do not manipulate the educational or pedagogical arrangements. This study attempted to find out the quality of prospective science teachers' PCK and discussed it strengths and weaknesses.

\section{Research Context}

This research conducted at the teacher professional development program in Indonesia who joined special program for prospective teachers (fresh graduates) who have served for a year in remote area. This program held for one year (two semesters). The first semester offered a workshop on the improving science learning understanding refered to subject-specific pedagogy (SSP) while the second one was conducted teaching practices in schools. The PNM is the first chemistry topic in the new curriculum for middle schools science classes which aims to distinguish the characteristics of solids, liquids and gases both macroscopically and sub microscopically (composition and motion of particles) followed by topics on elements, compounds and mixtures (Wahono, Rahmadiyati, \& Hidayati, 2016a; 2016b). Students at the middle school can start think abstract based on the piaget's theory (Gelman \& Baillargeon, 1983), where the chosen topic can be so associated with kinetic theory of matter, i.e. the composition and motion of particles in solids, liquids, and gases (Toplish, 2010; Nakhleh, Samarampungavan, \& Saglam, 2005; Ayas, Özmen, \& Çalık, 2010).

The specialty of the new curriculum content is the emphasis on scientific approach in the learning process (Majid, 2013) which to stimulate five science learning skills, namely observing, questioning, associating, experimenting, and networking. This is a good chalenge for the prospective teachers to implement effective learning strategies related to submicroscopic of matter topic. Some researchers have proven the effectiveness of learning strategies which can improve students' understanding, e.g. demonstrations using real object to describe particle motion (Boz \& Boz, 2008; Tsai, 1999), role playing demonstration (Tsai, 1999; Purvis, 2006), and computer animation (Boz \& Boz, 2008).

\section{Subject and Data}

All subjects in this study are prospective teachers who have just graduated from the science education study program from three state universities in Java, Indonesia, who have an average age of the same, i.e. 23-24 years old with one year teaching experience. Sample consisted of five male (code Is, Zk, Rl, Tn and $\mathrm{Hr}$ ) and 
eleven female (Nr, Rs, Rn, Rr, Ms, Lt, De, Na, Ot, Bt, and $\mathrm{Ld}$ ). All of 16 prospective teachers (which were ratees) divided into three groups based on their teaching practice location in three public middle schools in Surabaya, Indonesia. The researchers videotaped their classroom activities and observed while teaching the PNM topic and colected their lesson plan. Then, there were six lecturers (acted as raters) who asked to assess the 16 teachers by using a rubric instrument which consisting of 12 items. Thus, total data collected was 16 teachers $\mathrm{x} 12$ items $\mathrm{x}$ 6 lectures $=1152$ and there was no missing data in this study.

\section{Instrument}

The researchers developed the PCK rubric instrument which designed to measure only three key components related a particular topic, (i.e., knowledge of science curriculum; knowledge of student understanding; knowledge of instructional strategies and representations for teaching science) among the five components suggested by Magnusson, et. al. (1999). The instrument consisting of 12 items to assess teachers' PCK which all items were organized based on the literature review on the PNM topic teaching which is proposed by some researchers, such as Boz \& Boz (2008); Tsai (1999); and Purvis
(2006). The descriptions of PCK components organized in rubric items are presented in the Table 1 each item in the rubric was rated on a four-point rating scale $(1=$ limited, $2=$ basic, $3=$ proficient, and $4=$ exemplary).

\section{Data Analysis}

The data collected was analyzed with MFRM, which is a development of rasch model measurement for the purpose of multi raters analysis. Firstly, the raw scores data of teachers' PCK observation using the rubric were collected from the six raters; then the data were keyed in into Microsoft Excel, after that a specific coding to analyses the data is prepared to be calculated by Facets software version 3.7.2. The MFRM analysis included in this study are three facets i.e. raters, prospective science teachers' PCK, and 12 items.

The MFRM calibration in this study is based on severity (C) of the raters (j); which affects the assessment of the probability of teachers' PCK (n) on rubric items (i) to determine the threshold category $(k)$ for the raters $(j)$ with the following equation:

$$
P_{n i k j} \frac{e^{\left(\beta_{n}-\delta_{i}-F_{k}-C_{j}\right)}}{1+e^{\left(B_{n}-\delta_{i}-F_{k}-C_{j}\right)}}
$$

Table 1. The Descriptions of the PCK Rubric Items

\begin{tabular}{|c|c|c|c|}
\hline PCK Component & Description & Item Code & Source \\
\hline \multirow{3}{*}{$\begin{array}{l}\text { Knowledge of science } \\
\text { curriculum }\end{array}$} & Big idea of this topic & BIT & \multirow[t]{3}{*}{ Lesson plan } \\
\hline & Understanding the Sequencing learning & USL & \\
\hline & $\begin{array}{l}\text { Understanding about the importance of this } \\
\text { topic }\end{array}$ & UIT & \\
\hline \multirow{2}{*}{$\begin{array}{l}\text { Knowledge of students' } \\
\text { understanding in science }\end{array}$} & Understanding the prior knowledge & UPK & \multirow[t]{2}{*}{ Lesson plan } \\
\hline & Understanding the difficulty of this topic & UDT & \\
\hline \multirow{7}{*}{$\begin{array}{l}\text { Knowledge of } \\
\text { instructional strategies and } \\
\text { representations for teaching } \\
\text { science }\end{array}$} & Designing computer animations media & DCA & Lesson plan \\
\hline & Teaching by computer animation & TCA & Class observation \\
\hline & Designing the role playing media & DRP & Lesson plan \\
\hline & Teaching by role playing demonstration & TRP & Class observation \\
\hline & Designing real object media & $\mathrm{DRO}$ & Lesson plan \\
\hline & Teaching by real object observtion & TRO & Class observation \\
\hline & $\begin{array}{l}\text { Undertanding the weaknesses and Strengths of } \\
\text { the implemented teaching strategies }\end{array}$ & UWS & Reflection \\
\hline
\end{tabular}


This equation encloses teachers' PCK $\left(\beta_{\mathrm{n}}\right)$, rubric items' difficulty level $\left(\delta_{i}\right)$, the difficulty level threshold $\left(\mathrm{F}_{\mathrm{k}}\right)$, and raters' severity $\left(\mathrm{C}_{\mathrm{j}}\right)$ (Boone, Staver, \& Yale, 2014; Englehard, 2013). As an advancement of Rasch model, MFRM is a logistical measurement model based on probability then logarithm which is able to provide information on raters' accuracy, reliability, and validity, indices to be used as criteria are the value of outfit means-square (MNSQ), a standardized outfit (ZSTD), and point measure correlation (Pt.MeaCor) (Boone, et. al., 2014; Bond \& Fox, 2015; Linacre, 2017).

\section{RESULTS AND DISCUSSION \\ Result}

\section{The Quality of PCK Assessment Rubric Items}

The MFRM analysis of the data as Table 2 below presents a summary of the statistics on the reliability and separation index of both the items and the raters of the MFRM analysis results. Both of ratee and item reliability is classified as very good for a measurement, its value more than .8 (Bond \& Fox, 2015; Linacre, 2013).

The high item reliability shows that all items define the latent variable well. This means that the twelve items can be relied upon and can be used in different groups of respondents. Whereas the item separation index shows item difficulty range (Perera, Sumintono, \& Jiang, 2018). In this study, the item separation index of 5.0 and value of standard deviation clearly indicates a good distribution of item difficulty (Fisher, 2007). This criterion shows that this PCK assessment instrument is suitable and reliable to identify the science teachers's PCK. Whereas separation index for ratee indicates how well this rubric can assess "people's ability" in terms of latent nature, namely PCK in teaching that specific topic.

Table 2. Reliability and Separation Report of MFRM Analysis

\begin{tabular}{llllll}
\hline & Logit Mean & $\begin{array}{l}\text { Standar } \\
\text { Deviation }\end{array}$ & $\begin{array}{l}\text { Separation } \\
\text { Index }\end{array}$ & Reliability & $\begin{array}{l}\text { Standard } \\
\text { Error }\end{array}$ \\
\hline Ratee & .00 & .90 & 2.98 & .90 & .29 \\
Item & .00 & 1.50 & 5.0 & .97 & .27 \\
\hline
\end{tabular}

Table 3. Psychometrics Attributes of Items

\begin{tabular}{|c|c|c|c|c|c|c|c|}
\hline \multirow{2}{*}{ Item } & \multirow{2}{*}{ Measure } & \multirow{2}{*}{$\begin{array}{l}\text { Model } \\
\text { S.E. }\end{array}$} & \multicolumn{2}{|c|}{ Infit } & \multicolumn{2}{|c|}{ Outfit } & \multirow{2}{*}{$\begin{array}{c}\text { Correlation } \\
\text { PtMea }\end{array}$} \\
\hline & & & MNSQ & ZSTD & MNSQ & ZSTD & \\
\hline TCA & 2.13 & .34 & 1.80 & 2.0 & 2.18 & 1.5 & .62 \\
\hline DRP & 1.91 & .42 & .74 & -.5 & .47 & -.7 & .86 \\
\hline DCA & 1.91 & .42 & .74 & -.5 & .47 & -.7 & .86 \\
\hline TRP & 1.63 & .30 & 1.69 & 2.0 & 1.67 & 1.3 & .68 \\
\hline UWS & -.13 & .21 & 1.15 & .8 & 1.24 & 1.1 & .62 \\
\hline DRO & -.40 & .21 & 1.12 & .6 & 1.15 & .8 & .59 \\
\hline TRO & -.40 & .21 & 1.12 & .6 & 1.15 & .8 & .59 \\
\hline BIT & -.65 & .21 & .61 & -2.4 & .61 & -2.2 & .80 \\
\hline UIT & -1.15 & .22 & .83 & -.8 & 1.03 & .2 & .68 \\
\hline USL & -1.37 & .22 & .96 & -.1 & .84 & -.6 & .79 \\
\hline UPK & -1.37 & .22 & .96 & -.1 & .84 & -.6 & .79 \\
\hline UDT & -2.12 & .25 & .99 & .0 & 1.53 & 1.8 & .41 \\
\hline Mean & .00 & .27 & 1.06 & .1 & 1.10 & .2 & .69 \\
\hline SD & 1.44 & .08 & .35 & 1.2 & .49 & 1.2 & .13 \\
\hline
\end{tabular}


The overall quality of rubric items for assessing teacher's PCK is shown at in Table 3. It is found that the logit values of all items/measure fall within +2 SD and -2SD (all between +2.88 to -2.88 logit) indicating that there is no outlier item. The Measure correlation point values fall within $.32<\mathrm{x}<.8$ (all positive) suggesting that all items are in accordance with the agreed latent variables. The indices of outfit MNSQ value should be between $.5-1.5$, the table shows that at least three items above it (item TCA, TRP and UDT) which consider not good for measurement but outfit ZSTD and point measure correlation still okay for measurement. The MFRM analysis of all items also shows high unidimensionality of items based on the minimum of $40 \%$ variance in Rasch Model (Engelhard, 2013). In this study, the Variance is $60.98 \%$ suggesting that all items in the instrument is measure one dimension.

\section{Prospective Science Teachers' PCK}

The analysis results of prospective science teachers' $P C K$ using MFRM is shown in the second column of Figure 1 (the simultaneous measurement of logit distribution of prospective teachers' PCK) and PCK assessment rubric items about "the particulate nature of matter" is in the third column. The first column ("logit scale") is sorted from the lowest to the highest. Logit distribution scale is in a mean zero logit (Boone, et, al., 2014). The result shows that the prospective science teachers (ratee) are within zero logit meaning that they have average ability.

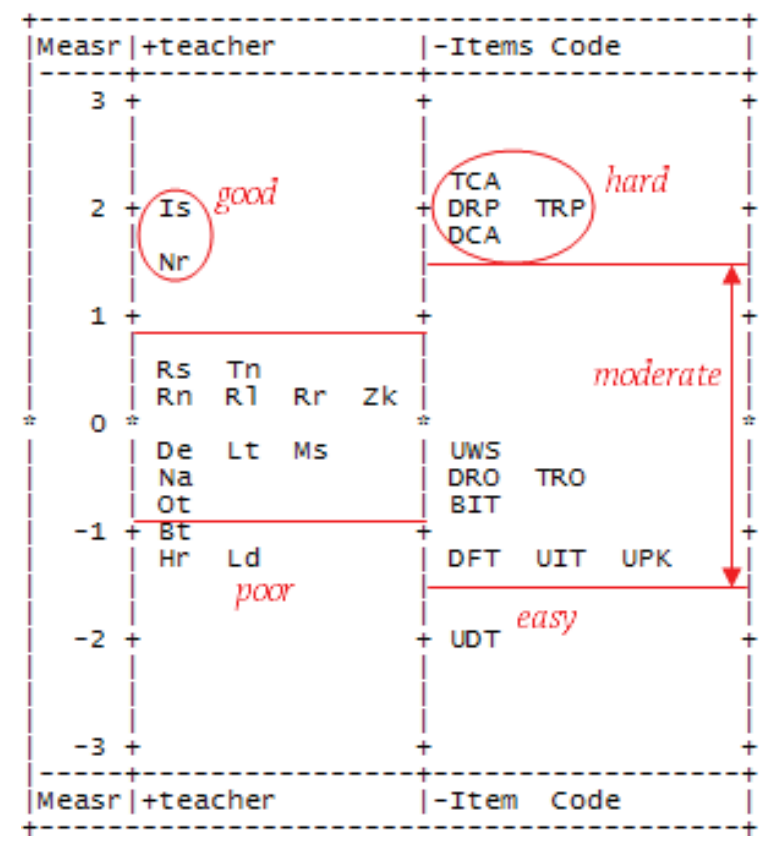

Based on Figure 1 and Table 3, the ratee's distributionlogitis within +2.13 to-2.12 and sorted from the lowest to the highest with mean values of .0 and SD .90 (see Table 2). A prospective teacher with initial Is has the highest logit while a prospective teacher called Ld has the lowest one (the second column). The SD value is essential to classify the prospective teachers' PCK. The ratee with logit higher than the SD demonstrate good comprehension on PCK, the ratee with logit lower than -SD has poor comprehension on PCK, and those with the in between demonstrate moderate comprehension on PCK (Perera, et. al., 2018). The second column of Figure 1 shows that prospective teachers with initials Is and $\mathrm{Nr}$ are ratees with the best comprehension on PCK. The other 9 ratees (Rs, Tn, Rl. Rr, Na, Nr, Zk, Ot and $\mathrm{Lt})$ have moderate PCK while the rests $(\mathrm{Bt}, \mathrm{Hr}$ and $\mathrm{Ld}$ ) have poor PCK. This categorization of ratee into three groups is supported by the index separation value (Table 3 ) for the ratee. In each category of teachers' PCK abilities, five male teachers spread in three groups, i.e. one male in good teacher (Is), three males in the moderate ( $\mathrm{Tn}, \mathrm{Zk}$, and $\mathrm{Rl}$ ) and one male (Hr) in the poor group.

\section{The PCK Item Calibration}

The Table 4 shows distribution of 12 PCK item calibration, which is item difficulty level (logit value item or LVI as appear in the Table 3) based on raters assessment to the performance of prospective teachers. The classification of the items into three difficulty level was done by dividing the distribution of the item logit score based on mean and standard deviation values. There were 4 items (33\%) in difficult category (LVI $>+1.44$ logit); 7 items $(58 \%)$ in the moderate category $(+1.44 \geq \mathrm{LVI} \geq-1.44)$ and one items $(9 \%)$ in the easy category (LVI $<$ -1.44 logit). Overall, raters rated the prospective teachers were good in the first two dimensions, which are in knowledge of science curriculum and knowledge of students' understanding in science; but the prospective teachers still struggle in terms of knowledge of instructional strategies and representations for teaching science dimension.

Figure 1. Variable Map of Ratee and Items 
Table 4. PCK Item Calibration

\begin{tabular}{llll}
\hline \multirow{2}{*}{ Dimension } & Difficulty level & & \\
\cline { 2 - 4 } & Difficult & Moderate & Easy \\
\hline Knowledge of science curriculum & - & BIT, USL, UIT & - \\
Knowledge of students' understanding & - & UPK & UDT \\
Knowledge of instructional strategies & TCA, DRP, DCA, TRP & UWS, DRO TRO & - \\
\hline
\end{tabular}

Prospective teacher skills in understanding student ability show they know better, even the raters rated they capable of understanding the difficulty of PNM topic (item UDT). This showing that the prospective teachers have study and include that in their lesson plan and teaching preparation. Understanding of the PNM subject also not having problem by the prospective teachers, they are capable of that.

Meanwhile, component of "knowledge of instructional strategies and representations for teaching science" dimension is classified as difficult and moderate items. On that component, items related to the use of computer animationbased learning strategies and role playing demonstration are classified as 'difficult' items (DCA, DRP, TRP \& TCA). Two items which are assosiated to the use of learning strategies by real objects include are 'moderate' items (DRO and TRO); and one item connected to their understanding of the weaknesses and strengths of the learning strategies (UWS) they use are also classified as 'moderate' items.

The assessment of all raters revealed these four items (DCA, DRP, TRP \& TCA) are not mastered by most participants. Only two participants with high person logit (good teachers), i.e. Is and $\mathrm{Nr}$ master these four items (see Figure 1). DCA item is related to teachers' ability to design learning assisted with computer animation learning media. The use of learning media is to help students to comprehend the arrangement and particle movement of solids, liquids, and gases. Meanwhile, TCA is an item that represents teachers's ability to implement computer-based animation learning in classrooms. In addition, DRP item represents teachers's ability to design learning processes using role playing demonstration to help students in understanding the arrangement and particle movement of matter; and item TRP is used to assess the teacher's ability to implement role playing demonstrations in their respective classes.

\section{Disscussion}

Teaching and learning is a complex task; thus, it is very important for prospective teachers to be able to distinguish between the different components included in teaching practice. The ability to identify each component in the teaching practice receive wide attention from educational researchers, especially in the context of science education to assess and improve the PCK of prospective science teachers (Park, et. al., 2011; Park \& Oliver, 2008). This research area is full of challenges due to their difficulties in conceptualizing PCK (Aydeniz \& Kirbulut, 2014).

In this study, we develop instruments to measure teachers PCK on specific topic "The particulate nature of matter" (PNM) and has been proved reliable and valid after being analyzed with many facet rasch models (MFRM). Thus, it can be used to assess teachers' PCK in different sample groups. In addition, prospective teachers and in-service teachers should pay attention to important elements for effective teaching (Grossman, 2011; Bryan \& Abell, 1999).

PCK teachers' skill in this research devided into three groups, i.e. good, moderate and poor, where two teachers in good teacher, eleven teachers in moderate and three teachers in poor one. All samples have the same educational background, age and teaching experience. The overall samples are dominated by female, but all five male teachers are spread almost equally across three categories (good, mederate and poor). This shows that male and female teachers have the same potency to develop their PCK skills.

The results of this study suggest that the prospective middle school teachers' PCK for teaching "The particulate nature of matter" or PNM is relatively low, because only $12.5 \%$ of prospective teachers have high PCK. This result is not surprising considering that the participants are novice teachers (Baxter \& Lederman, 1999; 
NRC, 1996; Van Driel, et. al., 2002) and PCK is directly related to the practice of teaching and learning which is a complex task (Grossman, 2011). Exploring the PCK development for prospective teachers who participate in a year training program is quite interesting because quality of Indonesian teachers is of great interest (De Ree, et. al., 2018). In addition, assessment and analysis of each PCK component in a teacher training program or teacher professional development is useful for evaluating and designing the next program.

Analysis with MFRM clearly illustrates the teacher's ability in three PCK components, i.e. knowledge of science curriculum, knowledge of students'understanding in science and knowledge of instructional strategies and representations for teaching science (Magnusson, et. al., 1999). The results indicate that the majority of teachers demonstrates low ability in terms of "knowledge of instructional strategies and representations for teaching science", while the prospective teachers have low understanding of knowledge of science curriculum and knowledge of students' understanding in science. These findings suggest that teachers' understanding of knowledge of science curriculum and knowledge of students' understanding in science influence the understanding of representations and conceptual teaching strategies. This is in line with Sen, Oztekin \& Demirdogen (2018) that content knowledge supports knowledge of learning strategies and even students' understanding of science.

The MFRM analysis, revealed that they prefer the use of real objects to learn the differences on the macroscopic nature of solids, liquids and gases. They have not been able to determine and implement effective learning strategies to understand their submicroscopic properties, namely differentiating the nature of particles in solids, and liquids. In fact, understanding of the submacroscopic nature is important to be mastered by middle school students, because this is the basis in learning other science concepts (Snir, et. al., 2003; Gabel, 1991). Learning the abstract nature of particles is a challenge for teachers, but middle school age students are already in the formal operational stage so teachers must be able to facilitate it (Toplish, 2010; Nakhleh, et. al., 2005; Ayas, et. al., 2010).
The very striking result in this study is the majority of prospective teachers do not master computer animation-based learning strategies to visualize the distance and motion of particles in matter. Even though they are millennials who are already familiar with information technology. Likewise by visualizing it using real objects with role playing demonstration where both of these strategies have been proven effective to facilitate students in understanding the kinetic theory of matter related to the distance and motion of particles in solids, liquids and gases (Tsai, 1999; Purvis, 2006; Boz \& Boz, 2008).

This case shows that most of science teachers in the case of the professional teacher development program are still struggle to teach science at middle school level. It indicated area for professional development in Indonesia (De Ree, et. al., 2018). Most teachers in the study need to be trained in designing and implementing effective learning strategies. They seem to be more subject to regulation and bureaucracy, so, they conducted learning in class as what is guided in the teacher's manual on the implementation of the latest curriculum. This is in line with Bjork's (2005) finding that teachers in Indonesia are reluctant to improve authority and independence (teaching creativity). This is possibly due their limited competences in terms of content knowledge and pedagogical knowledge. This assumption needs to be proven by further research, although some studies have shown that teacher competence in Indonesia is indeed low (De Ree, et. al., 2018).

These results provide benefits for both prospective science teachers and teacher educators. The prospective teachers gain insight that teaching is not simple, but there is knowledge and understanding that must be possessed. Deeper content knowledge will guide them in establishing the right learning sequence and perspective for middle school students on that topic. In addition, the teachers will be inspired to teach the science concepts appropriately and effectively (Grossman, 2011) for middle school students. The PNM topic is very useful as a basis for learning other scientific concepts (Haidar, 1997; Snir, et. al., 2003; Tsai, 1999). In the end, the teachers reflect on whether the learning strategies that have been implemented are effective to help students gain the right concepts of science. When both prospective 
science teachers and teacher educators are aware that PCK is related to how teachers teach a specific topic to help students understand science concept comprehensively, teacher educators should more emphased on TSPCK in teacher professional development (Van Driel \& Berry (2012; Gess-Newsome, 2015). Each topic has its own characteristics, so teacher training will not be effective if it is carried out en masse, both in terms of the number of training participants and in the content curriculum training (Nealsen, 2003).

This study is limited to only explore the middle school science teachers' PCK on a specific topic "The particulate nature of matter". PCK-based teacher professionalism should be directed at teaching certain topics (Gess-Mewsome, 2015). Thus, this research is expected to motivate PCK research on various topics of teaching at various levels of school and other disciplines. Given the relatively low quality of Indonesian education, using PCK to improve the quality of teaching in the context of teacher professional development is important (Loughran, et. al., 2004; Van Driel \& Berry, 2012).

\section{CONCLUSION}

MFRM analysis has provided complete information related item quality, item difficulty and the ability of prospective science teachers' PCK. Those information includes the ability of PCK in each of its components which is useful in analyzing the strengths and weaknesses of teachers of professional competence. The majority of respondent in this case, need to improve their PCK specifically in terms of Knowledge of instructional strategies and representations for teaching science". The analysis results show that most of prospective teachers are still struggle to teach science at the middle school level because they are not optimal in teaching differences in the submicroscopic nature of materr. Most of them are still dominant in teaching differences in solid, liquid and gas based on macroscopic nature. Mastery of effective learning strategies related to the arrangement and distance of particles in the matter is still low, such as the using of computer animation and role playing demonstrations to describe the distance and motion of particles in solids, liquids and gases. The ability of PCK in the components of Knowledge of science curriculum" and "Knowledge of students' understanding in science is also only at a moderate level.

\section{ACKNOWLEDGEMENTS}

This research funded by the Director General of Research and Development Strengthening the Ministry of Research, Technology and Higher Education of the Republic of Indonesia No. 3 / E / KPT / 2018.

\section{REFERENCES}

AAAS, American Association for the Advancement of Science. (1993). Dialogue on early childhood science, mathematics, and technology education. Washington, DC: Author.

Abell, S. K. (2008). Twenty years later: Does pedagogical content knowledge remain a useful idea? International Journal of Science Education, 30(10), 1405-1416. doi:10.1080/09500690802187041.

Al-Samarrai, S., Chang, M. C., Ragatz, A. B., Shaeffer, S., Stevenson, R., \& De Ree, J.J. (2013). Teacher reform in Indonesia: The role of politics and evidence in policy making: Main Report (English). Directions in development, Human development. Washington DC: World Bank Group.

Ayas, A., Özmen, H. \& Çalık, M. (2010). Students' conceptions of the particulate nature of matter at secondary and tertiary level. International Journal of Science and Mathematics Education, 8(1), 165-184. doi:10.1007/s10763-009-9167-x.

Aydeniz, M. \& Kirbulut, Z. D. (2014). Exploring challenges of assessing pre-service science teachers' pedagogical content knowledge (PCK), Asia-Pacific Journal of Teacher Education, 42(2), 147-166. doi :10.1080/1359866X.2014.890696.

Ball, D. L., Thames, M. H., \& Phelps, G. (2008) Content knowledge for teaching: What makes it special? Journal of 
Teacher Education, 59(5), 389-407. doi: $10.1177 / 0022487108324554$.

Baxter, J. A., \& Lederman, N. G. (1999). Assessment and measurement of pedagogical content knowledge. In J. Gess-Newsome \& N. G. Lederman (Eds.), Examining pedagogical content knowledge (pp. 147-163). Boston, MA: Kluwer.

Bjork, C. (2005). Teachers, schools, and central bureaucracy ( $1^{\text {st }}$ ed.). New York, NY: Routledge.

Bond, T. G., \& Fox, C. M. (2015). Applying the rasch model, fundamental measurement in the human sciences $\left(3^{\text {rd }}\right.$ ed.). NewYork, NY: Routledge.

Boone, W. J., Staver, J.R., \& Yale, M.S. (2014). Rasch Analysis in the Human Sciences. Dordrecth: Springer.

Boz, N. \& Boz, Y. (2008). A qualitative case study of prospective chemistry teachers' knowledge about instructional strategies: Introducing particulate theory. Journal of Science Teacher Education, 19(2), 135156. doi:10.1007/s10972-007-9087-y.

Bryan, L. A., \& Abell, S. K. (1999). Development of professional knowledge in learning to teach elementary science. Journal of Research in Science Teaching, 36, 121-139. doi:10.1002/(SICI)1098$2736(199902) 36: 2<121::$ A I D TEA2>3.0.CO;2-U.

Davidowitza, B. \& Potgieterb, M. (2016). Use of the Rasch measurement model to explore the relationship between content knowledge and topic-specific pedagogical content knowledge for organic chemistry. International Journal of Science Education, 38(9), 1483-1503. doi:10.108 0/09500693.2016.1196843.

De Ree, J., Muralidharan, K., Pradhan, M. \& Rogers, H. (2018). Double for nothing? Experimentalevidence on an unconditional teacher salary increase in Indonesia The
Quarterly Journal of Economics, 133(2), 993-1039. doi:10.1093/qje/qjx040.

Engelhard, Jr, G. (2013). Invariant measurement: Using Rasch models in the social, behavioral and health sciences. New York, NY: Routledge.

Fisher, W. P. Jr. (2007). Rating scale instrument quality criteria. Rasch Measurement Transactions, 21(1), 1095.

Gabel, D. (1991). Improving chemistry achievement through emphasis on the particle nature of matter. Paper presented in annual meeting of National Association for Research in Science Teaching, Lake Geneva, Wisconsin.

Gess-Newsome, J. (2015). A model of teacher professional knowledge and skill including. In A. Berry, P. Friedrichsen, \& J. Loughran (Eds.), Re-examining pedagogical content knowledge in science education (pp.28-42). New York, NY: Routledge.

Gelman, R. \& Baillargeon, R. (1983). A review of Piagetian concepts, chapter in Paul H Mussen, Hand book of child psycology, 4th edition. Vol. 1. New York, NY: John Willey \& sons.

Grossman, P. (2011). Framework for teaching practice: A brief history of an idea. Teachers College Record, 113(12), 28362843.

Haidar, A. H. (1997). Prospective chemistry teachers' conceptions of the conservation of matter and related concepts. Journal of Research in Science Teaching, 34(2), 181-197. doi:10.1002/(SICI)10982736 (199702) $34: 2<181:$ : A ID TEA $5>3.0 . C O ; 2-\mathrm{P}$.

Harrison, A. G., \& Treagust, D. F. (2002). The particulate nature of matter: Challenges in understanding the submicroscopic world. In J. K. Gilbert, O. De Jong, R. Justi, D. F. Treagust \& J. H. Van Driel (Eds.), Chemical education: 
Towards a research-based practice (pp. 189-212). The Netherlands: Kluwer Academic Publishers. doi:10.1007/0-30647977-X 9.

Henze, I. \& Van Driel, J. (2015). Toward a more comprehensive way to capture PCK in its complexity. In A. Berry, P. Friedrichsen \& J. Loughran (Eds). Re-examining pedagogical content knowledge in science education: Teaching and learning in science series (pp 120-134). New York, NY: Routledge Press.

Henze, I., Van Driel, J. H. \& Verloop, N. (2008). Development of experienced science teachers' pedagogical content knowledge of models of the solar system and the universe, International Journal of Science Education, 30(10), 1321-1342. doi:10.1080/09500690802187017.

Kind, V. (2009). Pedagogical content knowledge in science education: perspectives and potential for progress. Studies in Science Education, 45(2), 169-204. doi:10.1080/03057260903142285.

Linacre, J. M. (2017, Autumn 2017). Teaching Rasch Measurement, Rasch Measurement Transactions, 31(2), 1630-1631.

Linacre, J. M. (2013). A User's Guide to FACETS Rasch-Model Computer ProgramsVersion3.71.3. Chicago: Winsteps.

Loughran, J., Mullhall, P.J , \& Berry, A. (2004). In search of pedagogical content knowledge in science: Developing ways of articulating and documenting professional practice. Journal of Research in Science Teaching, 41(4), 370-391. doi:10.1002/ tea. 20007.

Loughran, J. J., Berry, A. K., \& Mulhall, P. J. (2006). Understanding and developing science teachers' pedagogical content knowledge. ( $1^{\text {st }}$ ed.). Rotterdam, Netherlands: Sense Publishers.
Magnusson, S., Krajcik, L., \& Borko, H. (1999). Nature, sources and development of pedagogical content knowledge. In J. Gess-Newsome \& N. G. Lederman (Eds.), Examining pedagogical content knowledge (pp. 95-132). Dordrecht, Netherlands: Kluwer. doi:10.1007/0-30647217-1_4.

Majid, A. (2013). Implementasi Kurikulum 2013 kajian teoritis dan praktis. Bandung, Indonesia: PT. Remaja Rosdakarya.

Mavhunga, E. \& Rollnick, M. (2011). Improving PCK of Chemical Equilibrium in Preservice Teachers. African Journal of Research in Mathematics, Science and Technology Education, 17(1-2), 11325. doi:10.1080/10288457.2013.828406.

Mavhunga, E. \& Rollnick, M. (2013). Improving PCK of chemical equilibrium in pre-service teachers, African Journal of Research in Mathematics, Science and Technology Education, 17(1-2), 113-125. doi:10.1080/10288457.2013.828406.

Nakhleh, M. B., Samarampungavan, A. \& Saglam, Y.(2005). Middle school students' beliefs about matter. Journal of Research in Science Teaching, 42(5), 581-612. doi: 10.1002/tea.20065.

NRC, National Research Council. (1996). National science education standard. Washington, DC: National Academic Press.

NCATE, National Council for Accreditation of Teacher Education. (2001). Professional standards for the accreditation of schools, colleges, and departments of education. Washington, DC: Author.

Nealsen. H. D., (2003). Reforms to teacher education in Indonesia: Does more mean better?, Asia Pacific Journal of Education, 18(2), 9-25. doi:10.1080/0218879980180203. 
Nilsson, P. (2008). Teaching for understanding: The complex nature of pedagogical content knowledge in pre- service education. International Journal of Science Education, 30(10), 1281-1299. doi:10.1080/09500690802186993.

NSTA, National Science Teaching Association. (1995). NSTA standards for science teacher preparation. Arlington, VA: Author.

Park, S., \& Oliver, J. S., (2008). Revisiting the conceptualisation of pedagogical content knowledge (PCK): PCK as a conceptual tool to understand teachers as professionals. Research in Science Education, 38(3), 261-284. doi:10.1007/ s11165-007-9049-6.

Park, S., Jang, J. Y., Chen, Y-C., \& Jung, J. (2011). Is Pedagogical Content Knowledge (PCK) necessary for reformed science teaching? Evidence from an empirical study. Research in Science Education, 41(2), 245-260. doi:10.1007/s11165-0099163-8.

Park, S. \& Suh, J. K. (2015). From portraying toward assessing PCK: drivers, dilemmas, and directions for future research. In A. Berry, P. Friedrichsen \& J. Loughran (Eds). Re-examining pedagogical content knowledge in science education, teaching and learning in science series (pp 104119). New York, NY: Routledge Press.

Perera, C. J., Sumintono, B., \& Na, J. (2018). The psychometric validation of the principal practices questionaire based on item response theory. International Online Journal of Educational Leadership, 2(1), 21-38. doi:10.22452/iojel.vol2no1.3.

Pitjeng, P. (2014). Novice unqualified graduate science teachers'topic specific pedagogical content knowledge, content knowledge and their beliefs about teaching. In $\mathrm{H}$. Venkat, M. Rolnick, M. Askew \& J. Loughran (Eds). Exploring mathematics and science teachers' knowledge: windows into teacher thinking (pp. 6583). Abingdon, England: Routledge.

Postholm, M. B. (2012). Teachers' professional development: A theoretical review. Educational Research, 54(4), 405-429. do i: $10.1080 / 00131881.2012 .734725$.

Purvis, D. (2006, January). Fun with Phase Changes, NSTA Web News Digest Science and Children Feature. Retrieved from http://www.nsta.org/publications/ news/story.aspx?id=51497.

Rahman, B., Abdurahman, A., Kadariyanto, B., \& Rusminanto, N. E. (2015). Teacher based scaffolding as a teacher professional development program in Indonesia. Australian Journal of Teacher Education, 40(11), 67-78. doi:10.14221/ ajte.2015v4on11.4.

Rohaan, E. J., Taconis, R., \& Jochems, W. M. G. (2009). Measuring teachers' pedagogical content knowledge in primary technology education. Research in Science \& Technological Education, 27(3), 327-338. doi:10.1080/02635140903162652.

Sen, M., Öztekin, C. \& Demirdöğen, B. (2018). Impact of content knowledge on pedagogical content knowledge in the context of cell division, Journal of Science Teacher Education, 29(2), 102-127. doi:1 0.1080/1046560X.2018.1425819.

Smith, P. S., \& Banilower, E. R. (2015). Assessing PCK: A new application of the uncertainty principle. In A. Berry, P. Friedrichsen, \& J. Loughran (Eds.), Re-examining pedagogical content knowledge in science education, teaching and learning in science series (pp. 88-103). New York, NY: Routledge.

Shulman, L. (2015). PCK its genesis and exodus. In A. Berry, P. Friedrichsen \& J. Loughran (Eds), Re-examining pedagogical content knowledge in science education, teaching and learning in science series (pp 104119). New York, NY: Routledge Press. 
Sumintono, B. \& Subekti, N. B. (2015). Teacher in-service training and re-training in Indonesia. In Karras, K. G. \& Wolhuter, C. C. (Eds.). International Handbook of Teacher Education, Training and Retraining Systems in the modern World. Nicosia, Cyprus: Studies and Publishing.

Snir, J., Smith, C. L. \& Raz, G. (2003). Linking phenomena with competing underlying models: A software tool for introducing students to the particulate model of matter. Science Education, 87(6), 694-830.

Tamir, P. (1988). Subject matter and related pedagogical knowledge in teacher education. Teaching \& Teacher Education, $4(2), \quad 99-110 . \quad$ doi:10.1016/0742051X(88)90011-X.

Toplis, R. (2010). Learning to teach science in the secondary school: A companion to school experience ( $3^{\text {rd }}$ ed.). New York, NY: Routledge.

Tsai, C. C. (1999). Overcoming junior high school students' misconceptions about microscopic views of phase change: A study of an analogy activity. Journal of Science Education and Technology, 8(1), 83-91. doi:10.1023/A:1009485722628.

Van Driel, J. H., De Jong, O., \& Verloop, N. (2002). The development of pre-service chemistry teachers' PCK. Science Education, 86(4), 572-590. doi:10.1002/ sce. 10010
Van Driel, J. H. \& Berry, A. (2012). Teacher professional development focusing on pedagogical content knowledge. Educational Researcher, 41(1), 26-28. doi:10.3102/0013189X11431010.

Van Dijk, E. M. \& Kattmann, U. (2006). A research model for the study of science teachers' PCK and improving teacher education. Teaching and Teacher Education, 23(6), 885-897. doi:10.1016/j. tate.2006.05.002.

Wahono, W. Rahmadiyati, F. \& Hidayati, S. N. (2016a). Buku Guru IPA SMP Kelas VII (edisi revisi). Jakarta, Indonesia: Pusat Kurikulum dan Perbukuan, Balitbang, Kemdikbud.

Wahono, W. Rahmadiyati, F. \& Hidayati, S.N. (2016b). Buku Siswa IPA SMP Kelas VII (edisi revisi). Jakarta, Inodesia: Pusat Kurikulum dan Perbukuan, Balitbang, Kemdikbud.

Widodo, A. \& Riandi, R. (2013). Dual-mode teacher professional development: challenges and revisioning future TPD in Indonesia. Teacher Development, 17(3), 380-392. doi: 10.1080/13664530.2013.81 3757.

Williams, P. J., \& Lockley, J. (2012). Using CoRes to develop the pedagogical content k (PCK) of early career science and technology teachers. Journal of Technology Education, 24(1), 34-53. doi:10.21061/jte.v24i1.a.3. 